Dominika Wyrzykiewicz

Warszawa

\title{
POLACY W ŻYCIU KULTURALNYM BERLINA W PIERWSZEJ DEKADZIE XXI WIEKU
}

\author{
- Czy musi się mieć ojczyznę? [...] Ziemi rodzinnej \\ tak naprawdę nie mam. Jeśli istnieje jakieś miejsce, \\ w którym choć trochę odnajduje poczucie ziemi \\ rodzinnej, to jest nim Berlin
}

(Marcel Reich-Ranicki)

Po drugiej wojnie światowej Polskę opuściło ponad dwa miliony osób, które osiedliły się na terenie dzisiejszej Republiki Federalnej Niemiec. Na przestrzeni dwóch stuleci z terytorium Polski przemieściło się do Niemiec ponad 8 milionów osób ${ }^{1}$. Obecnie w Berlinie mieszka około 40 tysięcy obywateli Polski, chociaż wliczając liczbę polskich przesiedleńców legitymujących się niemieckim paszportem liczba ta może wynosić nawet ponad sto tysięcy ${ }^{2}$. Grupa ta jest zróżnicowana pod względem społecznym i ekonomicznym. Znajdują się w niej zarówno pracownicy fizyczni, jak i umysłowi, naukowi. Pomimo bardzo licznej na przestrzeni wieków migracji Polaków do stolicy Niemiec, polska historia Berlina stanowi całkowicie nieznany wątek w kulturowej świadomości berlińczyków, a nazwiska najwybitniejszych przedstawicieli polskiej emigracji popadły $\mathrm{w}$ zapomnienie. Żadna tablica pamiątkowa na miejscu dzisiejszego Reichstagu nie przypomina o stojącym przed laty $\mathrm{w}$ tym miejscu pałacu polskiego

${ }^{1}$ Zob. M. Nowosielski, Polacy w Niemczech. Stan badań i perspektywy badań, „Przegląd Zachodni" 2012, nr 3, s. 3.

${ }^{2}$ W numerze 3 "Przeglądu Zachodniego" z 2012 roku w artykule Polacy w Niemczech. Stan badań i perspektywy badań Michał Nowosielski podaje, że liczba osób o podłożu migracyjnym (bez przesiedleńców) w 2007 roku w Berlinie wynosiła 46 tysięcy, w 2010 roku (z przesiedleńcami) 79 tysięcy, a w 2011 roku liczba migrantów - obywateli polskich kształtowała się na poziomie 36 tysięcy (M. Nowosielski, op. cit., s. 14). 
hrabiego Atanazego Raczyńskiego, w którym mieściła się największa w Berlinie, dostępna dla publiczności prywatna galeria obrazów. Atanazy Raczyński był nie tylko wybitnym mecenasem kultury i sztuki, ale także autorem pierwszej cenionej historii współczesnej sztuki niemieckiej ${ }^{3}$.

Na próżno szukać w Berlinie informacji o tym, że właścicielem barokowego pałacu Schulenburgów przy ul. Wilhelmstrasse 77 (dzisiaj 93) był książę Antoni Radziwiłł, utalentowany muzycznie, autor muzyki do Fausta Goethego. Berliński pałac Radziwiłłów stanowił centrum życia kulturalnego Berlina, a po roku 1810 zapewniał namiastkę życia dworskiego. Wśród znamienitych gości salonu artystycznego księcia Radziwiłła byli m.in. Fryderyk Chopin, Felix Mendelssohn Bartholdy, Ludwig van Beethoven, Johann Wolfgang von Goethe i Karl Friedrich Schinkel ${ }^{4}$. Po śmierci Antoniego Radziwiłła, dzięki poparciu jego wnuka Wilhelma, na dworze cesarza Wilhelma II pracowali wybitni polscy malarze Julian Fałat i Wojciech Kossak. Mniej więcej w tym samym czasie twórcy berlińskiej bohemy jak Edward Munch i August Strindberg skupili się wokół określanego mianem "genialnego Polaka" Stanisława Przybyszewskiego 5 . W 1875 roku Rzesza niemiecka kupiła pałac Radziwiłłów, który przebudowany został na siedzibę kanclerza. Także na tablicy pamiątkowej na miejscu wspomnianego budynku nie widnieje żadna wzmianka o rodzie Radziwiłłów, którego losy są przecież doskonałym przykładem związków kulturalnych i politycznych między Polską a Prusami w Berlinie ${ }^{6}$. Z polskiej rodziny szlacheckiej pochodzili obrońca Berlina przed wojskami napoleońskimi, Johannes Gockowski oraz założyciel słynnej Prusko-Królewskiej Manufaktury porcelany, malarz i grafik Daniel Chodowiecki, późniejszy dyrektor Berlińskiej Akademii Sztuk Pięknych i ilustrator dzieł wielu autorów niemieckich?

Od ponad wieku Berlin stanowi drugi po Zagłębiu Rury największy ośrodek emigracji polskiej w Niemczech. Na początku XX wieku działało tu 31 stowarzyszeń akademickich, 8 organizacji politycznych, 25 towarzystw śpiewaczych, 6 towarzystw szkolno-oświatowych i bardzo wiele różnorodnych organizacji i zrzeszeń rzemieślników, przedsiębiorców, sportowców, robotników ${ }^{8}$. Stolica Niemiec przyciągała Polaków nawet $\mathrm{w}$ czasach trudnych pod względem ekonomicznym i politycznym

${ }^{3}$ R. Traba, My, polscy berlińczycy, „Dialog” 2008-2009, nr 85-86, s. 54.

${ }^{4}$ Por. M. Kalczyńska, L. Paszek, My berlińczycy!, http://www.polonika.opole.pl/html/ polber2.htm (28.12.12).

${ }^{5}$ Por. R. Traba, My, polscy berlińczycy, „Dialog” 2008-2009, nr 85-86, s. 54.

${ }^{6}$ Por. B. Kerski, Berlin, polska metropolia kultury, „Dialog” 2008-2009, s. 41-44.

7 Zob. R. Traba, „My, berlińczycy! Wir Berliner!” Polacy w rozwoju Berlina (XVIII$X X I$ w.), http://www.cbh.pan.pl/index.php?option=com_content\&view=article\&id=45\&catid=21\&Itemid=136\&lang=pl (28.12.12).

${ }^{8}$ Por. B. Kerski, Berlin, polska metropolia kultury, „Dialog” 2008-2009, s. 45. 
jako centrum kultury, nauki i sztuki. To właśnie w Berlinie u Ernsta Lubitscha karierę rozpoczęła polska aktorka Pola Negri, późniejsza światowa gwiazda kina niemego ${ }^{9}$, w latach trzydziestych triumfy na scenach stolicy Niemiec święcił śpiewak Jan Kiepura. W 1935 roku doszło do uroczystego otwarcia Instytutu Niemiecko-Polskiego w Berlinie ${ }^{10}$.

Oprócz obywateli polskich, którzy osiedlili się w Berlinie zaraz po zakończeniu II wojny światowej oraz po wydarzeniach w Polsce w 1956 i 1968 roku, istotna dla roli i znaczenia berlińskiej Polonii była migracja młodych Polaków w latach siedemdziesiątych i osiemdziesiątych XX wieku, popularna szczególnie ze względu na bliskie sąsiedztwo między obydwoma krajami. Berlin Zachodni był dla Polaków, żyjących w komunistycznym kraju, przystanią wolności. Polacy osiedlający się w stolicy Niemiec przejawiali różne formy aktywności politycznej, religijnej, kulturalnej i gospodarczej, pojawiły się polskie media, powstało polskie duszpasterstwo katolickie oraz polskie wspólnoty. Do pierwszych organizacji i stowarzyszeń należały, nieistniejące już Towarzystwo Solidarność, Grupa Robocza Solidarność, Zjednoczenie Polskich Uchodźców oraz Polska Rada Społeczna. Oprócz nich w latach 80. i 90. działały także wydawnictwa publikujące czasopisma o charakterze polityczno-kulturalnym, jak np. biuletyn informacyjny Przekazy, Biuletyn Informacyjny, miesięcznik Archipelag, czasopismo Poglad, kwartalnik SŁOWO, Biuletyn Polskiej Rady w Niemczech ${ }^{11}$.

Dzięki liberalizacji przepisów paszportowych w Polsce, Berlin Zachodni stał się w latach 70. i 80. dla wielu Polaków miastem, do którego przybywali coraz liczniej młodzi artyści i twórcy. Wraz ze stale rosnącą liczbą emigrantów, problemami na rynku pracy oraz na rynku mieszkaniowym, stosunek władz Berlina Zachodniego do emigrantów z Polski zmienił się z czasem radykalnie na negatywny. „Polacy w latach 80 . byli pod wieloma względami postrzegani z dużym dystansem - wspomina pełnomocnik Senatu Berlina do spraw obcokrajowców Barbara John - Ich napływ był dla niektórych Niemców małą inwazją. Nikt tak na dobrą sprawę nie wiedział, co z nimi zrobić"12. Emigranci z Polski przedstawiani byli jako „handlarze na czarno”, „przemytnicy”, „nielegalni robotnicy”. Jednak pomimo tego wypaczonego obrazu dosyć szybko zintegrowali się ze społeczeństwem niemieckim, nie tylko pod względem ekonomicznym, ale także kulturowym i społecznym ${ }^{13}$. Znaczące było zwłaszcza zaangażowanie

${ }^{9}$ Por. Ibidem, s. 46.

10 Zob. P. Buras, Polski Berlin. Opowiemy wam waszą historię, http://wyborcza.pl/1,97738, 6511519,Polski_Berlin__Opowiemy_wam_wasza_historie.html (28.12.12).

11 Zob. My berlińczycy! Wir Berliner! Historia polsko-niemieckiego sasiedztwa, (red.) R. Traba, Berlin 2009, s. 81.

${ }^{12}$ Zob. B. Kerski, Berlin, polska metropolia kultury, „Dialog” 2008-2009, s. 48.

${ }_{13}$ Zob. My berlińczycy! Wir Berliner! Historia polsko-niemieckiego sasiedztwa, (red.) R. Traba, Berlin 2009, s. 82 . 
artystów, aktorów, reżyserów, kompozytorów, dyrygentów, nauczycieli muzyki, śpiewaków, malarzy, rzeźbiarzy, pisarzy, dziennikarzy i publicystów w życie kulturowe Berlina oraz ich istotny wpływ na kształt kultury w stolicy Niemiec. Dzięki stypendiom Fundacji Forda, DAAD, programom zachodnioniemieckiego Rządu Federalnego, zachodnioberlińskiej Akademii Sztuki i Literarisches Colloqiums Berlin oraz staraniom Karla Dedeciusa utalentowani pisarze np. Witold Gombrowicz, Marek Hłasko, Witold Wirpsza, Adam Zagajewski, Kazimierz Brandys, Zbigniew Herbert, Wiktor Woroszylski, Ewa Lipska a obecnie także Olga Tokarczuk, Dorota Masłowska, Wojciech Kuczok i wielu innych mogli odwiedzać Berlin, co nie pozostało bez śladu w ich twórczości. Częstymi bywalcami stolicy Niemiec, a szczególnie berlińskich muzeów byli m.in. Zbigniew Herbert, Tadeusz Różewicz, Tomek Tryzna. Pisarze polscy wybierali i nadal wybierają Berlin ze względu na jego wielojęzyczność i otwartość na świat. Podkreślając tę właśnie wielokulturowość Leszek Szaruga napisał we wspomnieniach, zamieszczonych w Magazynie Polsko-Niemieckim DIALOG w numerze poświęconym Polskiemu Berlinowi: „Wybrali Berlin [...] właśnie dlatego, że $\mathrm{w}$ jakimś sensie przypominał [...] przedwojenne Wolne Miasto Gdańsk, które nie było [...] nigdy miastem polskim czy niemieckim, lecz przede wszystkim hanzeatyckim [...]. Mój Berlin był miastem emigrantów, nie tylko polskich. Był swoistą, jak to określają fizycy, osobliwością - jako taki stał się kanwą świetnej powieści Dziady berlińskie wybitnego malarza i eseisty Henryka Wańka: stanowił bramę do „innego świata" [...]"14. W swoich wspomnieniach poeta Ryszard Krynicki podkreśla przede wszystkim, że podczas pobytu w Berlinie mógł spokojnie pracować „,[b]ez żadnych trosk, za co będę żył jutro. Mogłem robić wszystko to, co lubię. Mogłem czytać, mogłem tłumaczyć - przełożyłem bardzo wiele wierszy niemieckojęzycznych poetów [...]. Mogłem oglądać obrazy, które kocham, mogłem do nich wracać, to jest bardzo ważne"15. Dla polskich pisarzy Berlin stanowił wyspę wolności ,[...] dzięki pobytowi w nim, mogli po prostu poczuć się wolni. [...] mieszkali tam Katarzyna i Zbigniew Herbertowie. Ale też Witold Wirpsza i Maria Kurecka. Często także przyjeżdżali inni pisarze: Tadeusz Różewicz, Stanisław Lem - byłem na jego wieczorze w Akademie der Künste. [...] spotkałem Wiktora Woroszylskiego, który był na dłuższym stypendium i Kazimierza Brandysa z żoną Marią"16.

\footnotetext{
${ }^{14}$ L. Szaruga, Brama do innego świata. Wspomnienia, „Dialog” 2008-2009, s. 72, 74.

${ }^{15}$ K. Fortuna, Wyspa wolności. Rozmowa DIALOG-u z Ryszardem Krynickim, poeta i wydawca o Berlinie, „Dialog” 2008-2009, s. 79.

${ }^{16}$ Ibidem, s. 80.
} 
Także Andrzej Stasiuk ${ }^{17}$ i Krzysztof Niewrzęda czują się w Belinie jak w domu, zwłaszcza w jego wschodniej części, która ich zdaniem bardzo przypomina Polskę. Architektura stolicy Niemiec, place, ronda, szerokie ulice, parki ale także sposób życia i zachowanie mieszkańców budzą szczególne skojarzenia ze Szczecinem, z Polską ${ }^{18}$.

Ważki wpływ na życie literackie Polonii w Berlinie wywarli przede wszystkim pisarze wywodzący się z kręgu emigracji solidarnościowej: Maria Kolenda, Iwona Mickiewicz, Ewa Czerwiakowska, Andrzej Szulczyński, Piotr Olszówka, Basil Kerski, Wojtek Mróz, Joanna Wiórkiewicz, Viktoria Korb, Jacek Tyblewski, Krzysztof Rottermund, a w późniejszym okresie Krzysztof Niewrzęda i Artur Szlosarek ${ }^{19}$, publikujący zarówno w języku polskim, jak i niemieckim, organizujący spotkania literackie, tworzacy towarzystwa literackie, jak np. powstałe w 1994 roku Polsko-Niemieckie Towarzystwo Literackie i wydawnictwo Wir, Klub Polskich Nieudaczników wraz z wydawanym przez niego czasopismem Kolano.

Współcześnie żyje w Berlinie wielu polskich lub polskojęzycznych dziennikarzy radiowych i prasowych, których artykuły ukazują się w renomowanych mediach $w$ Polsce i Niemczech. Jednym z nich jest wybitny krytyk literacki, urodzony we Włocławku w rodzinie żydowskiej Marcel Reich-Ranicki. Ponadto od 2009 roku w ramach programu rozgłośni WDR Funkhaus Europa emitowany jest polskojęzyczny program radiowy „Radio Multikulti po polsku". Redakcję polską tworzą m.in.: Jacek Tyblewski, Elżbieta Stasik, Dorota Kerski, Krzysztof Visconti i Tomasz Kycia. W Berlinie wydawane jest polsko-niemieckie czasopismo Magazyn Polsko-Niemiecki DIALOG ${ }^{20}$.

Polską tradycję muzyczną, zapoczątkowaną przez Artura Rubinsteina, Ignacego Paderewskiego, Feliksa Nowowiejskiego czy Władysława Szpilmana kontynuują obecnie pochodzący z Polski młodzi kompozytorzy, muzycy, pianiści i pianistki, śpiewacy operowi i dyrygenci. Są wśród nich muzycy Opery Niemieckiej, np. skrzypek Tomasz Tomaszewski - pierwszy koncertmistrz oraz Orkiestry Berlińskich Filharmoników ze skrzypkiem, pierwszym koncertmistrzem Danielem Stabrawą i dyrygentem Markiem Janowskim. Historia Orkiestry Berlińskich Filharmoników

17 Zob. A. Stasiuk, Dojczland, Wołowiec 2007.

${ }_{18}$ Zob. Niewrzęda, Czas przeprowadzki, Szczecin 2005, s. 48. Zob. też A. Górajek, Berlin - mit fremden Augen gesehen. Aus Reisenotizen polnischer Schriftsteller, [w:] Deutsch-polnische Beziehungen in Kultur und Literatur, (red.) L. Kolago, K. Grzywka, Warszawa 2009, s. 103-110.

${ }_{19}$ Por. M. Kalczyńska, L. Paszek, My berlińczycy!, http://www.polonika.opole.pl/html/ polber2.htm (28.12.12).

${ }^{20}$ Por. My berlińnzycy! Wir Berliner! Historia polsko-niemieckiego sasiedztwa, (red.) R. Traba, Berlin 2009, s. 83. 
związana jest ściśle z działalnością polskich instrumentalistów. Muzykiem, który zapoczątkował działalność Polaków w orkiestrze był skrzypek Tadeusz Hanicki, rozpoczynający karierę jeszcze w zespole Benjamina Bilse, przekształconym z czasem w Orkiestrę Filharmoników Berlińskich ${ }^{21}$. Tadeusz Hanicki potrafił „w świecie muzycznym niemieckim zająć stanowisko wybitne, gdzie pozyskał szacunek najznakomitszych powag"22. Wiele lat później (1957-1986) członkiem orkiestry zostali Michel Schwalbé, urodzony w Radomiu skrzypek o francusko-polskich korzeniach oraz Edward Zienkowski (1978-1981). Obecnie w skład Orkiestry Berlińskich Filharmoników wchodzi pięciu Polaków: grający na altówce Zdzisław Polonek (od 1981 roku), wspomniany już skrzypek Daniel Stabrawa (od 1983 roku), kontrabasista Janusz Widzyk (od 2001 roku) oraz od 2009 roku Ignacy Miecznikowski (altówka) i Krzysztof Polonek (skrzypce) ${ }^{23}$.

Oprócz muzyków klasycznych uznaniem cieszą się także muzycy rockowi, popowi i jazzowi oraz polsko-niemieckie zespoły muzyczne jak np. „Bloody Kishka” czy „Harthoff”, zespół Jazz-Duett e.V., dwunarodowy chór „Spotkanie”, a w dziedzinie muzyki folklorystycznej zespół „Szuroki”24.

$\mathrm{Na}$ uwagę zasługuje znacząca liczba polskich przedstawicieli sztuki teatralnej, którzy przenosząc do Niemiec doświadczenia polskiej szkoły teatralnej Tadeusza Kantora, Henryka Tomaszewskiego raz teatru eksperymentu Jerzego Grotowskiego w istotny sposób wpłynęli na kształt teatru berlińskiego. Szczególnym zainteresowaniem i uznaniem, zwłaszcza w latach 90., cieszył się Teatr Kreatur Andrzeja Worona, odgrywający nawet przez pewien czas wiodącą rolę wśród teatrów berlińskich. Popularność zyskały jego sztuki Unsere grosse Familie, Hallo und adieu, Yerma. Andrzej Woron opisywał swój teatr jako budzący wspomnienia "album rodzinny”. "Moim ideałem jest - mówił Woron - rodzaj symbiozy między człowiekiem, rekwizytem i ruchem. [...] Przedmioty muszą posiadać samodzielną jakość, tak aby każdy z elementów scenografii mógł w dowolnym momencie trafić do galerii i być wystawionym jako obiekt czy instalacja" 25 . Niespodziewany sukces przyniosła Teatrowi Kreatur inscenizacja Sklepów Cynamonowych Schulza, dzięki czemu w 1992 roku teatr Worona został zaproszony jako pierwszy teatr offowy do udziału w festiwalu teatrów niemieckich Berliner Theatertreffen ${ }^{26}$.

${ }^{21}$ Zob. http://www.berliner-philharmoniker.de/berliner-philharmoniker/orchestergeschichte (28.12.2012).

22 A. Rajchman, Od Redakcyi, „Echo Muzyczne, Teatralne i Artystyczne”, 1896, R. 13, nr 9 (648), s. 109, http://ebuw.uw.edu.pl/dlibra/plain-content?id=3009 (28.12.2012).

${ }^{23}$ Zob. http://www.berliner-philharmoniker.de/berliner-philharmoniker/das-orchester (28.12.2012).

${ }^{24}$ Por. Ibidem, s. 86.

${ }^{25}$ Ibidem, s. 296-297.

${ }^{26}$ Por. Ibidem, s. 297. 
Teatr polski w Berlinie, nie tylko wspomniany już Teatr Kreatur, ale także Teatr Studio przy Salzufer jest pełen wyrazu, bogaty w przekaz metaforyczny, język obrazu i ruchu, jest to swoisty teatr-misterium. Przy Teatrze Studio, prowadzonym przez Janinę Szarek i prof. Olava Münzberga działa szkoła aktorska Transform-Schauspielschule z gronem doświadczonych wykładowców, m.in. Januszem Cichockim (dawniej w Teatrze Kreatur) i Zdzisławem Starczynowskim (mimem a wcześniej choreografem w teatrze A. Worona). Janina Szarek, dawna dyrektor działającego w Berlinie studia aktorskiego 'Gruppe 44', współpracuje ze znakomitymi polskimi reżyserami teatralnymi, m.in. z Krystianem Lupą ${ }^{27}$.

Oprócz wymienionych powyżej warto wspomnieć także Pantonimeschule, Theaterstudio Nawrot, Transform Schauspielschule ${ }^{28}$ oraz działający do 2001 roku teatr pantomimy Berlin Mime Company, założony przez Zdzisława Starczyńskiego i Andrzeja Jana Szczużewskiego, dwóch uznanych członków zespołu wielkiego mima Henryka Tomaszewskiego. Ponadto Transformtheater, utworzony w 1981 roku przez Henryka Baranowskiego i Bettinę Wilhelm, który miał za zadanie "transformację wrażeń i emocji na poziom teatru" ${ }^{\prime 29}$. Oprócz wystawiania sztuk teatralnych, w działającym do 2001 roku teatrze odbywały się warsztaty, prowadzone przez wybitnych artystów z Polski i zagranicy: Agnieszkę Holland, Krzysztofa Kieślowskiego, Andrzeja Wajdę, Erwina Axera, Andreja Tarkowskiego i Heiner Müllera ${ }^{30}$. Obecnie w Berlinie działają: Teatr Papierowy Zbigniewa Micha, Reduta Berlin Teresy Nawrot (teatr i prywatna szkoła teatralna) oraz Najprostszy Teatr Świata - Das einfachste Theater der Welt Piotra Szczaniowskiego ${ }^{31}$.

Z roku na rok w stolicy Niemiec osiedla się coraz więcej polskich twórców. Tworzą tutaj m.in.: Helena Bohle-Szacki, Stefan Dybowski, Elżbieta Woźniewska, Barbara Ur i Andrzej Piwarski ${ }^{32}$.

W dziedzinie malarstwa i grafiki charakter popularyzujący polską sztukę w Niemczech pełnią polsko-niemieckie galerie, np. galeria ZERO Anny Krenz i Jacka Slaskiego, zapewniająca artystom z Europy Wschodniej możliwość wystawiania ich dzieł, ponadto galeria MIEJSCE - der ORT Magdy Potorskiej, w której artyści ze wschodu i zachodu mogą realizować

27 Por. Ibidem, s. 297.

${ }_{28}$ Por. Ibidem, s. 87.

${ }^{29}$ Ibidem, s. 306.

${ }^{30}$ Por. My berlińczycy! Wir Berliner! Historia polsko-niemieckiego sasiedztwa, (red.) R. Traba, Berlin 2009, s. 306-307.

${ }^{31}$ Por. M. Kalczyńska, L. Paszek, My berlińczycy!, http://www.polonika.opole.pl/ html/polber2.htm (28.12.12).

${ }_{32}$ Por. M. Kalczyńska, L. Paszek, My berlińczycy!, http://www.polonika.opole.pl/ html/polber2.htm (28.12.12). 
wspólne projekty kulturalne i wymieniać się doświadczeniami ${ }^{33}$, Galeria Plakatu Polskiego Pigasus ${ }^{34}$ oraz istniejąca od 2007 roku Galeria Żak-Branicka, stanowiąca obecnie najważniejszą platformę prezentacji polskiej sztuki współczesnej. Wśród prezentowanych w galerii Żak-Branicka prac znajdują się dzieła trzech pokoleń artystów polskich. Najstarszą generację stanowią klasycy lat sześćdziesiątych i siedemdziesiątych: Józef Rybakowski i Zofia Kulik. Drugie pokolenie reprezentują Katarzyna Kozyra i Joanna Rajkowska. Przedstawicielką najmłodszych twórców jest Agnieszka Polska ${ }^{35}$.

Wśród bogatych tradycji malarstwa polskiego w Berlinie warto przypomnieć sztukę polskiej awangardy, artystów działających między Poznaniem a Berlinem: rzeźbiarza Franciszka Flauma, pisarza Stanisława Przybyszewskiego oraz malarza Stanisława Kubickiego, który zainspirowany przez berlińskich przyjaciół Georga Grosza i Raoula Hausmanna podejmował $\mathrm{w}$ swej twórczości eksperymenty dadaistyczne. Uznany za pierwszego przedstawiciela abstrakcji geometrycznej $\mathrm{w}$ Polsce, Kubicki przez wiele lat związany był z Berlinem i Poznaniem. Swoje teksty poetyckie pisał w dwóch językach, a wraz z żoną Niemką, Margarete Schuster, podejmował polsko-niemieckie inicjatywy wystawiennicze i wydawnicze oraz angażował się w działalność grupy artystycznej „Bunt”36. „Ekspresjoniści poznańscy pod przewodnictwem Kubickiego poważyli się naruszyć jednocześnie dwa tabu - prowokowali polskich patriotów promując sztukę niemiecką, a Niemców, propagując dzieła twórców z krajów alianckich $[\ldots]^{\prime \prime 37}$. W berlińskim domu Kubickich bywali najwybitniejsi przedstawiciel środowiska artystycznego: George Grosz, Else Lasker-Schüler, Marc Chagall, Alfred Döblin, Jankiel Adler z łódzkiej grupy Jung Idysz. Kubiccy znaleźli się także w gronie sześciu przedstawicieli Polski, obecnych na odbywającym się w 1922 roku Kongresie Międzynarodowym Unii Artystów Postępowych w Düsseldorfie ${ }^{38}$. Ostatnim sukcesem Kubickiego była indywidualna wystawa jego dzieł w berlińskim salonie niezależnych w 1931 roku. Wraz z rozwojem ruchu faszystowskiego awangarda przestała istnieć. Kubicki zginął podczas II wojny światowej z rąk gestapo. Syn

${ }^{33}$ Por. My berlinczycy! Wir Berliner! Historia polsko-niemieckiego sasiedztwa, (red.) R. Traba, Berlin 2009, s. 87.

${ }^{34}$ Por. M. Kalczyńska, L. Paszek, My berlińczycy!, http://www.polonika.opole.pl/ html/polber2.htm (28.12.12).

${ }^{35}$ Por. C. Fricke: Drehscheiben des Handels in Deutschland, http://www.handelsblatt. com/panorama/kunstmarkt/junge-kunst-aus-polen-drehscheiben-des-handels-in-deutschland/6027542.html (28.12.2012).

${ }^{36}$ Por. My berlińczycy! Wir Berliner! Historia polsko-niemieckiego sasiedztwa, (red.) R. Traba, Berlin 2009, s. 166, 172.

37 Ibidem, s. 177.

38 Por. Ibidem, s. 183. 
Kubickich należał do współzałożycieli Wolnego Uniwersytetu w Berlinie i był pierwszym spośród studentów immatrykulowanych na tej uczelni. Margarete Kubicka uczestniczyła jeszcze w 1961 roku w otwarciu wystawy Der Sturm, Herwath, Walden i Europejska Awangarda w Berlinie 1912-32, na której zaprezentowano także obrazy jej męża ${ }^{39}$.

Pielęgnowaniem polskich tradycji, obyczajów, kultury i języka w stolicy Niemiec zajmuje się wiele organizacji polonijnych i polsko-niemieckich, np. Polskie Towarzystwo Szkolne „Oświata”, Klub Polsko-Niemiecki VHS Wedding, Dom Polski - Polonicum, Polsko-Niemieckie Stowarzyszenie Kulturalne Polonica oraz Związek Polaków w Niemczech „Rodło”, Towarzystwo Niemiecko-Polskie w Berlinie, polsko-niemieckie stowarzyszenie kobiece Fraueninitiative Berlin-Warschau e.V., Instytut Polski i Centrum Badań Historycznych ${ }^{40}$, Polki w Gospodarce i Kulturze NIKE, Zjednoczenie Polaków w Berlinie, Polski Związek Kulturalny, wydający periodyk Gazetka, Polsko-Niemiecka Inicjatywa Kulturalna Polmost. Polacy w Berlinie angażują się w wielokulturowe projekty, np. Ökumenisches Frauenzentrum Evas Arche, Kobieta Szuka Przyszłości oraz w prace Polskiej Misji Katolickiej, organizującej oprócz bardzo wielu inicjatyw także koncerty muzyczne, np. w rocznicę śmierci bł. Jana Pawła II. Od 2005 roku przy Potsdamer Str. 63 działa Dom Polski „Polonicum”, w którym miesięcznie odbywa się około dziesięciu imprez kulturalnych, wystaw, koncertów, projekcji filmów, promocji polsko-niemieckich i polskich dokonań artystycznych, prowadzone są kursy tańca, spotykają się seniorzy i młodzież nie tylko o polskich korzeniach, ale także innych narodowości. Od 1956 roku w Berlinie działa Instytut Kultury Polskiej, szczególnie otwarty na potrzeby i zainteresowania odbiorcy niemieckiego, co nie zawsze spotyka się ze zrozumieniem berlińskich Polaków. Instytucja ta posiada jedną z większych bibliotek polskich w Niemczech. Od 1992 r. istnieje w Berlinie największe polskie wydawnictwo książkowe za granicą - firma Mordellus Press, prowadzona przez Piotra Mordela, współzałożyciela Klubu Polskich Nieudaczników (Club der polnischen Versager) ${ }^{41}$.

Dziś w wielokulturowym Berlinie rozwija się sztuka współczesna, mieszka wielu polskich artystów młodszej i starszej generacji. Wszyscy oni przyczyniają się do rozwoju życia kulturalnego stolicy Niemiec. Pełniąc rolę ambasadorów dwóch sąsiadujących ze sobą krajów, likwidują uprzedzenia i negatywne stereotypy we wzajemnych relacjach, organizują koncerty polskich muzyków, występy grup teatralnych, konferencje i wystawy dzieł sztuki ze zbiorów polskich muzeów a w ostatnich latach

${ }^{39}$ Por. Ibidem, s. 194-195.

${ }^{40}$ Por. Ibidem, s. 88.

${ }^{41}$ M. Kalczyńska, L. Paszek, My berlińczycy!, http://www.polonika.opole.pl/html/polber2.htm (28.12.12). 
wystawy, podkreślające wspólne korzenie kultury europejskiej, polskiej i niemieckiej oraz wzajemne oddziaływanie kultur. W 2009 roku w Ephraim Palais i Märkisches Museum odbyła się wystawa: MY BERLINCZYCY! Historia polsko-niemieckiego sasiedztwa, zorganizowana przez zespół Centrum Badań Historycznych PAN w Berlinie we współpracy z Städtisches Museum Berlin oraz Muzeum Narodowym w Poznaniu. Wystawa, stanowiąca największy projekt kulturalny jaki zrealizowano do tej pory w Berlinie, miała na celu przybliżenie niemieckiemu odbiorcy polskiej problematyki. W zaproszeniu na wystawę dyrektor Centrum Badań Historycznych Polskiej Akademii Nauk w Berlinie, prof. Robert Traba napisał: „Nie ma [bowiem] zamkniętych historii narodowych. Wszystkie dzieją się w szerszym kontekście. Punktem odniesienia staje się historia sąsiada. W przypadku Berlina "sąsiedzkość" ma podwójne znaczenie: wewnętrzne - Polacy jako integralna część społeczno-politycznego organizmu stołecznego Berlina, jako współobywatele; zewnętrzne - Polacy / Niemcy jako rzeczywisty i wyobrażony wizerunek sąsiada"42.

XXI wiek to czas, kiedy Polska obecna jest w najważniejszych strukturach światowych i europejskich, może korzystać z wolności i zdobyczy globalizacji. Trudno przecenić znaczenie otwartości granic, którą przyniosło przystąpienie do Unii Europejskiej. Umożliwiło to polskim artystom podróżowanie i konfrontację swoich wizji ze światowymi tendencjami, co przyniosło niespodziewanie dobre rezultaty.

Współcześni artyści pochodzenia polskiego mieszkający i tworzący w stolicy Niemiec kontynuują tradycję berlińskiej Polonii, wykazując się przy tym niezwykłą aktywnością, zauważalną i docenianą w berlińskich kręgach kulturalnych. Uznaniem niemieckich krytyków sztuki cieszy się twórczość Ewy Partum, mieszkającej i tworzącej od początku lat 80. w Berlinie. Artystka zafascynowana jest konceptualizmem jako dziedziną efemeryczną, która daje swobodę prowadzenia szeroko rozumianej działalności artystycznej. Obecnie powróciła do tworzenia poezji konkretnej ${ }^{43}$. Zainteresowanie berlińczyków wzbudza także bogata w odniesienia historyczne twórczość Wilhelma Sasnala, Mirosława Bałki oraz przełamujące tabu związane $z$ ciałem kobiecym fotografie, filmy i performance Katarzyny Kozyry. Z Berlinem związana jest Joanna Rajkowska. Urodzona w 1968 roku w Bydgoszczy artystka jest autorką wielu projektów plenerowych, m.in. plastikowej palmy w Alejach Jerozolimskich w Warszawie. W kręgu jej zainteresowań artystycznych znajduje się ciało ludzkie oraz bezsilność człowieka w obliczu choroby i rozkładu. Artystka zajmuje się także problematyką konfliktów ideologicznych, agresji wobec obcych oraz

\footnotetext{
${ }^{42}$ R. Traba, My, polscy berlińczycy, „Dialog” 2008-2009, nr 85-86, s. 54.

${ }^{43}$ Zob. A. Włodarczyk-Kulak, M. Kulak, O sztuce nowej i najnowszej, Warszawa-Bielsko-Biała 2010, s. 346.
} 
trudnościami adaptacyjnymi emigrantów i uchodźców, np. w pracach $A z y l$ dla uchodźców w Uhyst (2008), Przejażdżka wokół Wyspy Wojny (2004). Najnowszym projektem Rajkowskiej jest Born in Berlin. Pierwszą jego odsłonę stanowi film o tym samym tytule, wykonany dla 7. Biennale Sztuki Współczesnej w Berlinie, pokazywany w Akademie der Künste. Druga odsłona projektu - A Letter to Rosa, którą można oglądać w galerii Żak-Branicka, to zbiór ponad stu rysunków i kolaży, stanowiących rodzaj listu napisanego do córki Róży. Będąc w ciąży artystka podjęła decyzję, że miejscem narodzin jej córki będzie Berlin. „Róża przez całe życie na pytanie - Gdzie się urodziłaś? - będzie odpowiadać - w Berlinie. Dla Róży Berlin będzie się kojarzył z życiodajnym początkiem, choć pewnie nie będzie tego pamiętać. Pierwszy haust powietrza, pierwsze wydane przez nią dźwięki, pierwsza walka $z$ infekcją będą związane z tym miastem i nic tego nie zmieni. Róża jest moją odpowiedzią na Berlin. I darem dla tego miasta" mówi Rajkowska. [...] To miasto, które nie może udźwignąć swojej historii, które za wszelką cenę chce żyć chwilą teraźniejszą, rozkoszować się sobą, nieporównywalnym z niczym berlińskim powietrzem i stylem - zauważa. - Berlin nie chce być nagi, nie chce pokazywać ran, nie chce, po latach wojny i powojennej traumy, eksponować swojej bolesnej strony. Chce być ważną, kulturalną stolicą, elegancką, zimną i nowoczesną"44. Równolegle do projektu Born in Berlin w Instytucie Polskim w Berlinie pokazywana jest inna praca Rajkowskiej - Sumpfstadt - stanowiąca w założeniu artystki fotograficzną wizualizację „niemożliwego pomnika”, przywracającego centrum Berlina do „stanu natury”. Oprócz tego podczas 7. Biennale Sztuki Współczesnej artystka zaprezentowała film Final Fantasies, na którym pomagała ludziom wykreować okoliczności, w jakich chcieliby umrzeć. Born in Berlin, Sumpfstadt i Final Fantasies tworzą trylogię poświęconą miastu, życiu i śmierci ${ }^{45}$.

W galerii Żak-Branicka w okresie od stycznia do kwietnia 2012 prezentowana była wystawa Lux Aeterna innego polskiego artysty Huberta Czerepoka. Czerepoka interesuje granica między oświeceniem i opętaniem, dobrem i złem, a jego najnowsze prace koncentrują się na jednym $\mathrm{z}$ wielkich marzeń ludzkości, jakim jest osiągnięcie stanu wszechwiedzy ${ }^{46}$. Główne źródło prac artysty stanowią media, które regularnie śledzi, starając się znaleźć w nich sprzeczności współczesnego świata. Wystawa Lux Aeterna opowiada o marzeniu zapanowania nad światem dzięki wiedzy. Obrazuje to neon z napisem Madness is Like Gravity. Według Czerepoka szaleństwo

44 „Born in Berlin - A Letter to Rosa” - najnowszy projekt Joanny Rajkowskiej, http://www. culture.pl/kalendarz-pelna-tresc/-/eo_event_asset_publisher/L6vx/content/born-in-berlin-a-letter-to-rosa-najnowszy-projekt-joanny-rajkowskiej (28.12.12).

${ }^{45}$ Ibidem.

${ }^{46}$ Zob. http://www.polishculture-nyc.org, http://www.zak-branicka.com 
jest jak zawrót głowy: kusi w sposób niedostrzegalny, ale definitywny, jest nieodwracalne ${ }^{47}$. W 2012 roku artysta brał udział także w kolejnej wystawie, zorganizowanej przez galerię Żak-Branicka From the Sunniest Day to the Darkest Night, na której zaprezentował instalację Salvation Islands z 2009 roku. Przedstawia ona trzy przestrzelone stosy świętych ksiąg: Biblii, Koranu i Tanach (Biblii Hebrajskiej), ukazując w ten sposób problematykę związaną z upolitycznianiem sfery sacrum i wojnami w imię Boga. Religia jest dla artysty zarówno źródłem przemocy jak i osłoną przed złem $^{48}$.

Wśród artystów młodego pokolenia na uwagę zasługuje twórczość Roberta Kuśmirowskiego, którego instalacja Lichtung znalazła się na wystawie One on One, prezentowanej w berlińskim KunstWerke. Artysta, znany ze swoich instalacji, stanowiących pieczołowite fałszerstwa lub wierne kopie realnych obiektów i miejsc, w przestronnym wnętrzu stworzył cały krajobraz z piaskiem, drzewami i małym wzgórzem. Ta sceneria jest tylko pozornie miła, wystarczy bowiem okrążyć wzgórze, żeby naszym oczom ukazał się zupełnie inny obraz - leżące $\mathrm{w}$ rowie i bardzo realistycznie rozkładające się ciała trupów ${ }^{49}$.

Prace polskich artystów obecne są regularnie w Berlinie także na jednej z najważniejszych artystycznych imprez w Europie, Berlińskim Biennale Sztuki, odbywającym się co dwa lata i prezentującym dziesiątki prac najciekawszych współczesnych artystów (wśród których w 2012 roku na 7. Biennale znalazły się instalacje Joanny Rajkowskiej i Pawła Althamera) oraz najświeższe kuratorskie koncepcje. Kuratorem ostatniego, 7. Berlin Biennale został Polak - Artur Żmijewski, artysta kontrowersyjny, któremu krytycy zarzucili kicz, cynizm i mieszanie sztuki z polityką ${ }^{50}$. Organizacja 7. Biennale opierała się na współpracy z artystami, aktywistami, organizacjami, instytucjami sztuki spoza Berlina, np. Muzeum Sztuki Nowoczesnej w Warszawie oraz Centrum Sztuki Współczesnej Zamek Ujazdowski. „Prezentujemy sztukę - mówił Żmijewski podczas otwarcia Biennale która działa, pozostawia ślad w rzeczywistości oraz otwiera przestrzeń, w której można działać politycznie. Te prace tworzą wydarzenia polityczne - niezależnie od tego, czy dotyczą naglących problemów w społeczeństwie czy długoterminowej polityki pamięci" ${ }^{\prime \prime 1}$. W odpowiedzi na kuratorskie działania Żmijewskiego felietonista Frankfurter Allgemeine Zeitung (FAZ) Niklas Maak napisał, że choć kuratorzy Bienale mieli dobre pomysły, nie zastanowili się nad ich realizacją. Zabrakło przemyśleń,

\footnotetext{
${ }^{47}$ Zob. http://www.zak-branicka.com (28.12.2012).

${ }^{48}$ Por. http://www.polishculture-nyc.org, http://www.zak-branicka.com (28.12.2012).

49 Por. http://www.culture.pl/kalendarz-wydarzen (28.12.2012).

${ }^{50} \mathrm{http}: / /$ www.goethe.de/ins/pl/lp/kul/dup/bku/ber/pl8935615.htm (28.12.2012).

${ }^{51}$ http://www.culture.pl (28.12.2012).
} 
wiedzy i przesłania ${ }^{52}$. Recenzentka Der Spiegel Ulrike Knöfel stwierdziła, że „[w]ielu uczestników zaproszonych przez Żmijewskiego na Biennale nie jest $\mathrm{w}$ ogóle artystami albo sami się już w ten sposób nie postrzegają. Żmijewski używa ich, żeby okupować świat sztuki. Pokazuje powierzchowność art-worldu. I robi to poprzez każde prezentowane na Biennale dzieło, np. głowę Chrystusa polskiego rzeźbiarza Mirosława Pateckiego - pracę która chce być sztuką, a która w tym otoczeniu służyć może tylko za ilustrację absurdalnej i anachronicznej natury sztuki. Żmijewski i jego sojusznicy oddziałują w bardziej polemiczny i dogłębny sposób niż jest do tego przyzwyczajona scena sztuki. Ale to jest dokładnie to, czego scena sztuki, ze swoim uwielbieniem skandalu, chciała. [...]. Można powiedzieć, że Żmijewski wypowiada wojnę światu sztuki na jego własne życzenie. A świat sztuki, oscylując między samouwielbieniem i nienawiścią do siebie, z przyjemnością to wyzwanie podejmie ${ }^{\prime 53}$.

Szczególnym rokiem, w którym zaprezentowano bogatą ofertę sztuki polskiej w Berlinie był rok 2011. W związku z programem kulturalnym Polskiej Prezydencji w Unii Europejskiej Ministerstwo Kultury i Dziedzictwa Narodowego we współpracy z Instytutem Adama Mickiewicza, Narodowym Instytutem Audiowizualnym oraz Instytutem Polskim w Berlinie podjęło szereg inicjatyw, mających na celu prezentację polskiej sztuki i jej twórców. Do realizacji wspólnych projektów polsko-niemieckich udało się Instytutowi pozyskać dwie renomowane instytucje - Akademie der Künste (AdK), zrzeszającą artystów różnych dziedzin kultury i sztuki z wielu krajów oraz Berliner Festspiele. Najważniejszym wydarzeniem kulturalno-społeczno-politycznym stała się wystawa dotycząca wzajemnych relacji polsko-niemieckich na przestrzeni dziejów: Polska-Niemcy. 1000 lat sasiedztwa w Europie, zaprezentowana w prestiżowej galerii Martin-Gropius Bau w okresie 22.09.2011-9.01.2012. W skład Rady Programowej wystawy weszli m.in. prof. Władysław Bartoszewski, prof. Andrzej Rottermund, prof. Hubert Orłowski, prof. Jan Rydel, prof. Robert Traba oraz prof. Maria Poprzęcka a kuratorem wystawy została prof. Andy Rottenberg. W składzie niemieckiej części Rady Programowej znaleźli się prof. Dieter Bingen (dyrektor Deutsches Polen-Institut w Darmstadt), prof. Michael G. Müller (historyk Europy Wschodniej z Uniwersytetu Martina Lutra w Halle/Saale), prof. Christian Lübke (Dyrektor Centrum Nauk Humanistycznych

${ }^{52}$ S. Karich, Der Provokateur hat es nicht schwer, http://www.faz.net/aktuell/feuilleton/ kunst/berliner-kunst-kontroverse-der-provokateur-hat-es-nicht-schwer-11612750.html (28.12.2012) oraz R. Romaniec, Biennale w Berlinie: miażdzaca krytyka pod adresem polskiego kuratora, http://wiadomosci.onet.pl/raporty/deutsche-welle-w-onecie/biennale-w-berlinie-miazdzaca-krytyka-pod-adresem-,1,5177458,wiadomosc.html (28.12.2012).

${ }^{53}$ U. Knöfel, Auschwitz at the Biennale Polish Curator Lights a Fire under Berlin Art Scene, http://www.spiegel.de/international/zeitgeist/0,1518,829691-2,00.html (28.12.2012). 
Historii i Kultury Europy Środkowo-Wschodniej Uniwersytetu w Lipsku), prof. Gottfried Korf (badacz kultury, były pracownik Uniwersytetu w Tybindze), prof. Konrad Vanja (dyrektor Muzeum Kultur Europejskich - Staatliche Museen zu Berlin, Stiftung Preußischer Kulturbesitz), prof. Gertrud Pichan (Katedra Instytutu Europy Środkowo-Wschodniej na Wolnym Uniwersytecie w Berlinie). Celem wystawy była zmiana punktu widzenia przeciętnego mieszkańca Berlina nie tylko na polską historię, ale także na historię wspólnego sąsiedztwa polsko-niemieckiego ${ }^{54}$. Jednym z ciekawszych projektów, zrealizowanych w ramach programu, był cykl Zmiana Perspektywy (Blickwechsel), połączony z prezentacją dorobku multimedialnych artystów Zbigniewa Rybczyńskiego i Gabora Body w Akademii Sztuk Pięknych (AdK). Ważnym wydarzeniem była również wystawa instalacji wideo Mirosława Bałki, prezentująca w AdK przy Pariser Platz prace artysty od 1998 do 2010 roku. Dzięki współpracy Instytutu Polskiego z Międzynarodowym Festiwalem Literatury (internationales literaturfestival berlin) w stolicy Niemiec zaprezentowane zostały aktualne polskie projekty literackie i literacko-muzyczne. Współpraca z renomowaną instytucją festiwalową Berliner Festspiele, organizującą m.in. międzynarodowy festiwal teatru i tańca Spielzeit Europa zaowocowała prezentacją najnowszych spektakli polskich, m.in. Szosa Wołokołamska według Heiner Müllera w reżyserii Barbary Wysockiej w wykonaniu Teatru Polskiego z Wrocławia oraz MEDEA - spektaklu wyreżyserowanego przez Grzegorza Jarzynę $\mathrm{w}$ wiedeńskim Burgtheater ${ }^{55}$. Ponadto $\mathrm{w}$ wybranych kinach Berlina odbyła się retrospektywa Andrzej Wajda Komplett, obejmująca całokształt twórczości reżysera, połączona z dyskusjami i warsztatami filmowymi. Polscy muzycy jazzowi wzięli natomiast udział w odbywającym się od 40 lat berlińskim Festiwalu Jazzowym JazzFest, przyciągającym wybitnych jazzmanów z całego świata ${ }^{56}$.

Berlin stał się obecnie, obok głównych miast Polski, jednym z najważniejszych ośrodków kultury polskiej. Liczba artystów mieszkających $\mathrm{w}$ Berlinie, posiadających $\mathrm{w}$ ten lub inny sposób polski rodowód, jest znaczna i trudno ją określić, zwłaszcza, że środowisko polonijne jest tu, w odróżnieniu od Paryża lub Londynu, bardzo rozproszone. Także próba zdefiniowania sztuki polskiej nie jest łatwa, rodzi się bowiem pytanie, czy określenia narodowościowe w przypadku sztuki oraz jej twórców mają

${ }^{54}$ Zob. M. Wagińska-Marzec, Polska prezydencja w Radzie UE: Oprawa kulturalna (2011), „Biuletyn Instytutu Zachodniego" 2011, nr 52.

55 http://www.iz.poznan.pl/news/287_nr\%2052.\%20Oprawa\%20kulturalna\%20polskiej\%20prezydencji.pdf (28.12.2012).

${ }^{55}$ Ibidem.

${ }^{56}$ Ibidem. 
w ogóle rację bytu. Czym jest sztuka polska w Berlinie w obliczu zacierania granic i globalizacji, jakie są wpływy polskie w sztuce oraz jakie są artystyczne przemyślenia twórców polskich na temat zmieniającego się Berlina?

\section{Zusammenfassung}

Das künstlerische Berlin war seit dem 18. Jahrhundert bis zum Ende der Weimarer Republik eine attraktive Kunststadt für die modernen Künstler aus Polen. Mit der nationalsozialistischen Herrschaft nahm diese Tradition ein jähes Ende und geriet bis 1989 in Vergessenheit. Natürlich stand Berlin in keinem Vergleich zu den größten Kunstzentren wie Paris und Wien, doch es bot den osteuropäischen Künstlern eine Art Vorgeschmack der offenen, modernen Kunst.

Heute nimmt Berlin eine wichtige kulturelle Position für die jungen polnischen Künstler. Die Hauptstadt Deutschlands definiert sich als eine tolerante, multikulturelle Stadt mit einem breiten, vielfälltigen Kulturangebot. Ein wichtiger Teil dieses Angebots bilden die Werke der hoch geschätzten polnischen Künstler, Schriftsteller, Schauspieler, Musiker und Galeristen: Joanna Rajkowska, Paweł Althamer, Katarzyna Kozyra, Artur Żmijewski, Wilhelm Sasnal, Robert Kuśmirowski, Krzysztof Polonek, Daniel Stabrawa u.a. Sie nehmen an den wichtigsten internationalen Projekten teil und werden auf den prestigeträchtigsten Kunstmessen und in den namhaftesten Privatgalerien angeboten. Die annerkannten zeitgenössischen Künstler aus Polen arbeiten gern in Berlin, hier finden sie ihre Inspirationsquelle und ein aufnahmebereites Publikum. Mit ihrer künstlerischen Tätigkeit beeinflussen sie wesentlich das kulturelle Bild Berlins. 